\title{
Platelet function, factor VIII, fibrinogen, and fibrinolysis in Nigerians and Europeans in relation to atheroma and thrombosis
}

\author{
EVELYNE DUPUY, A. F. FLEMING ${ }^{1}$, AND J. P. CAEN
}

From the Department of Haemostasis and Experimental Thrombosis, Hôpital Lariboisière, 2, rue Ambroise Paré, 75475 PARIS CEDEX 10, France, and ${ }^{1}$ the Department of Haematology, Ahamdu Bello University, Zaria, Nigeria

SUMMARY Platelet function, factor VIII, fibrinogen levels, and fibrinolysis were studied in Europeans and in two groups of Nigerians living in Zaria, northern Nigeria, in order to see whether differences could help to explain the low incidence of atheroma and thrombosis in Nigerians. We confirmed the relative thrombocytopenia and observed a rapid disaggregation after ADP-induced platelet aggregation in Nigerians. The most striking difference was a reduced or absent ristocetin-induced platelet aggregation in Nigerian platelet-rich plasma, probably due to a plasma component interacting with the von Willebrand activity (VWF), since factor VIII coagulant activity, factor VIII related antigen, and isolated VWF were normal or high by European standards. Group II (rural population), but not group I (senior university staff in Zaria) of the Nigerians, tended to have high serum fibrinogen concentrations. Spontaneous fibrinolytic activity was enhanced in most Nigerians compare to the Europeans and was normally increased after venostasis in proportion to the initial activity Fibrinolysis and ristocetin-induced platelet aggregation values for the Nigerians in group I were intermediate between European and Nigerian in the group II values, suggesting that differences were due more to environmental than to genetic factors.

Relative thrombocytopenia, disaggregation after ADP-induced aggregation, inhibition of ristocetin-induced platelet aggregation, and active fibrinolysis help to explain the infrequency of thrombotic disease in Africans. Also the low incidence of atheroma may follow from less platelet adherence and less platelet release of mitogenic factors, which cause intimal hyperplasia.

There are wide geographical and racial differences in the incidence of atheroma (Restrepo, 1974; Shaper, 1974). It is rare in Nigerians (Parry and Ikeme, 1966; Edington and Gilles, 1975), and Akinkugbe (1972) reported 240 hypertensive patients in Ibadan (southern Nigeria) without any coronary accident during a two-year period of study; no ischaemic heart lesions were found at necropsy in 29 of these subjects.

As a population living on the Andes plateau presented no arterial thrombosis and their platelets did not respond to aggregating agents (Caen et al., 1971), we decided to compare the haemostatic mechanisms of Nigerians and Europeans living in northern Nigeria.

Received for publication 12 April 1978

\section{Subjects}

We compared one European group taken as a control with two groups of Nigerians.

EUROPEANS (CONTROLS)

We examined eight Europeans who had lived in Zaria for at least two years and 22 Europeans living in Paris.

NIGERIANS GROUP I

We studied 16 Nigerians, senior staff of the University of Ahmadu Bello (Zaria). They came from the south and north of Nigeria and their ethnic origin was either Ibos or Haoussa. Their life style and customs were similar to those of the Europeans, including their diet and way of life. 
NIGERIANS GROUP II

We examined 30 Nigerians who were blood donors and could be considered representative of the rural population of the Guinea savanna area of northern Nigeria. The ethnic origin of these Nigerians was Haoussa. They were mainly farmers or agricultural workers, their diet was less 'rich' than that of group I, and their serum cholesterol levels were lower. As a consequence of their occupations, the amount of physical exercise of this group was higher than that of the Europeans and group I Nigerians.

\section{Methods}

Blood samples ( 9 vol) were collected by venepuncture into 1 vol sodium citrate $38 \mathrm{~g} / \mathrm{l}$. The techniques that were applied have been described by Caen et al. (1975).

The platelet count was performed using Unopettes (Becton-Dickinson) and phase-contrast microscopy. Platelet aggregation was studied in a Bryston aggregometer (Labintec, Montpellier, France) on platelet-rich plasma (PRP) and on platelets isolated on an albumin-gradient, according to the method of Nicholls and Hampton (1972), as modified by Levy-Toledano and Bodevin (Caen et al., 1975). Albumin-gradient iso'ated platelets were resuspended in either their own platelet-poor plasma (PPP) or in a solution of human fibrinogen (Kabi AB, Stockholm, Sweden) $2.5 \mathrm{~g} / 1$ final concentration and gamma-globulins (Cohn fraction 1, Centre National de Transfusion Sanguine, Paris, France) $4 \mathrm{~g} / \mathrm{l}$ final concentration as aggregation-cofactors, and aggregation was expressed in terms of velocity and intensity. The aggregation in PRP was induced by the following agents: collagen (Stago, Asnières, France) $8 \mathrm{mg} / \mathrm{l}$ final concentration; ADP (Stago) $1.2 \mu \mathrm{mol}$ final concentration; ristocetin (Lundbeck, Copenhagen, Denmark) $1 \mathrm{~g} / 1$ final concentration. With albumin-gradient the same concentration of ristocetin was used, but the final concentration of ADP was $25 \mu \mathrm{mol}$.

Factor VIII coagulant activity (VIIIC) was measured in a one-stage assay using partial thromboplastin time and a haemophilic PPP as a substrate. von Willebrand factor (VWF) was tested by ristocetin-induced platelet-aggregation using the Weiss method slightly modified (Caen et al., 1975). VWF was determined in whole plasma and in plasma-fractions isolated after filtration on Sepharose 2B by which the high molecular weight fraction VWF was eluted in the void volume and separated from many other plasma-proteins. Factor VIII-related

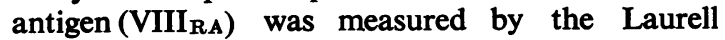
electroimmunodiffusion method using a commercial anti-human factor VIII antiserum (Behringwerke, Marburg, Germany).

Fibrinogen levels were estimated, and the euglobulin-lysis time was determined before and after venostasis (Lacombe et al., 1971).

\section{Results}

PLATELETS

The platelet count was $200 \times 10^{9} / 1(200000 / \mu \mathrm{l})$ or more in all Europeans except one. Five out of 16 Nigerians in group I and 10 out of 30 Nigerians in group II had counts of less than $150 \times 10^{9} / 1$

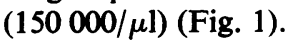

Platelet aggregation induced by ADP $1.2 \mu \mathrm{mol}$ was followed by spontaneous disaggregation in 12 out of 34 Nigerians of both social groups but was not seen in any of the Europeans. ADP-induced aggregation of isolated platelets from 12 Nigerians in group II was similar to that of 20 Europeans (tested in Paris) when resuspended either in their own plasma or in fibrinogen/gamma-globulin solution (Table 1).

The most striking difference between the Europeans and Nigerians was observed using ristocetin

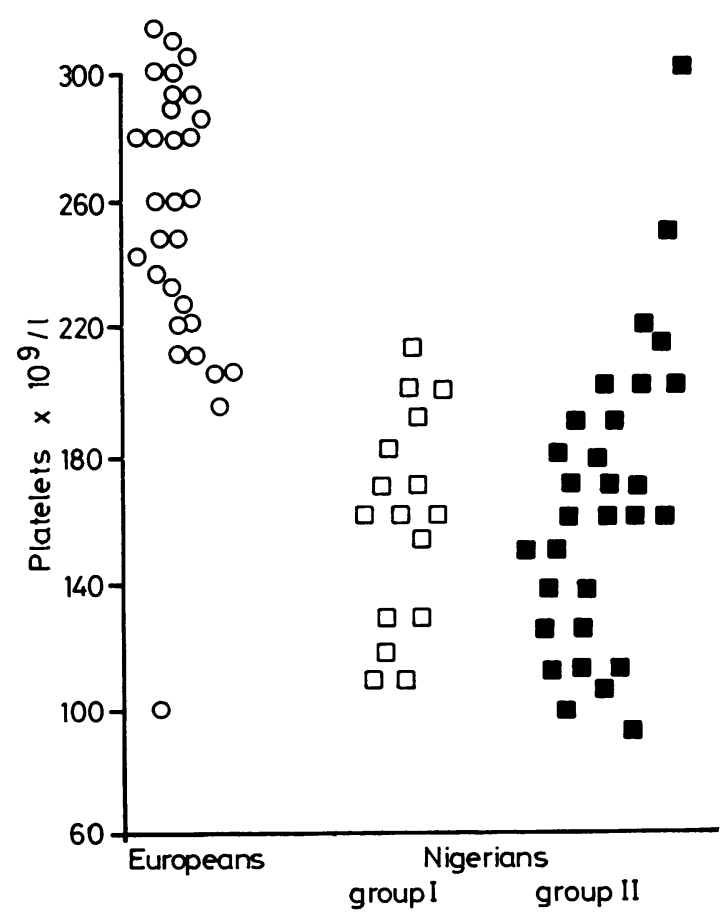

Fig. 1 Platelet counts in Europeans and Nigerians. groups I and II, in Zaria. 
Table 1 Aggregation induced by ADP $(25 \mu \mathrm{mol})$ in platelets isolated on an albumin-gradient and resuspended in plasma or fibrinogen plus gamma-globulins: Europeans compared to Nigerians (group II)

\begin{tabular}{lllc}
\hline Subjects & System added & $\begin{array}{l}\text { Aggregation velocity (\%) } \\
(\text { mean } \pm S D)\end{array}$ & $\begin{array}{l}\text { Aggregation intensity (\%) } \\
(\text { mean } \pm S D)\end{array}$ \\
\hline 20 Europeans & Fibrinogen $+\gamma$ globulins & $16 \pm 8$ & $38 \pm 7$ \\
(Paris control group) & Platelet-poor plasma & $16 \pm 8$ & $32 \pm 11$ \\
12 Nigerians & Fibrinogen $+\gamma$ globulins & 10.2 & $25 \pm 6$ \\
(group II) & Platelet-poor plasma & $12 \pm 2$ & $27 \pm 5$ \\
\hline
\end{tabular}

as aggregation-inducer in PRP (Fig. 2). The intensity of ristocetin-induced platelet aggregation was $50 \%$ or more in all the Europeans and in six of 16 Nigerians in group I, but for the other 10 Nigerians in this group the results were in the range $5-40 \%$. Six of the 17 Nigerians in group II had aggregation of $5 \%$ to $30 \% ; 11$ of 17 did not aggregate at all.

Ristocetin-induced aggregation of platelets for one Nigerian in group II was compared $(a)$ in his own PRP, (b) after isolation of platelets which were then resuspended in their own PPP in order to reconstitute a PRP, and $(c)$ after isolation, but tested in the presence of human fibrinogen and gamma-globulin solution. Ristocetin-induced aggregation was $(a)$ initially nil in PRP, and $(b)$ in reconstituted PRP, but $(c)$ became obvious in the absence of the subject's plasma but in the presence of human fibrinogen/gamma-globulin (Fig. 3). These results suggested an inhibitor of ristocetininduced platelet aggregation in the Nigerian's plasma, and the plasma of 11 out of 19 Nigerians in group II was found to inhibit to varying degrees the velocity of ristocetin-induced aggregation of

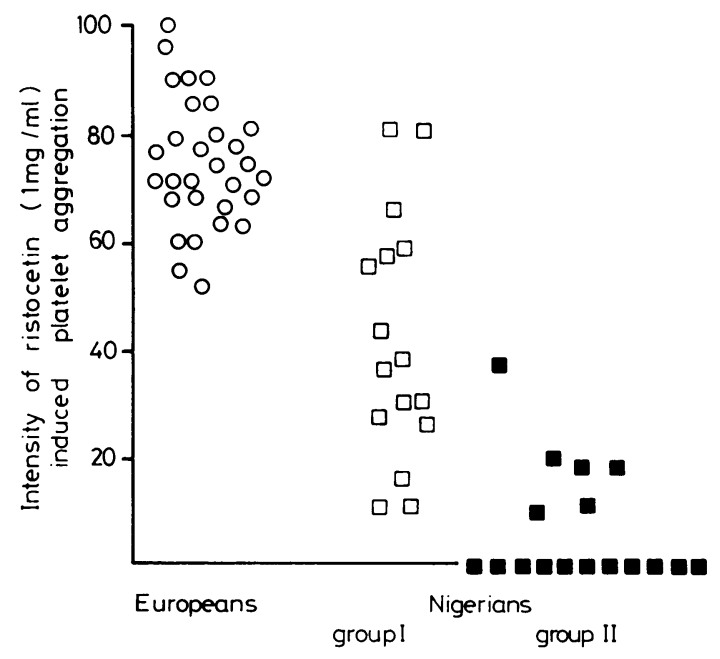

Fig. 2 Ristocetin-induced platelet aggregation in Europeans and Nigerians, groups I and II. washed filtered platelets from normal Europeans (Table 2).

FACTOR VIII

Nine out of 12 Nigerians in group I and 10 out of 16 in group II showed VIIIC above $150 \%$ of pooled European plasma. The remaining results fell into the range $100-140 \%$. VIII RA was above $100 \%$ of the European standard in all seven in group II $\overrightarrow{\vec{*}}$ tested. In two, the levels were as high as $340 \%$ and $460 \%$. VWF activity was estimated in whole plasma and on Sepharose $2 B$ isolated plasma-fraction from two group II Nigerians in whom VIII $I_{C}$ and VIII $_{\mathrm{RA}}$

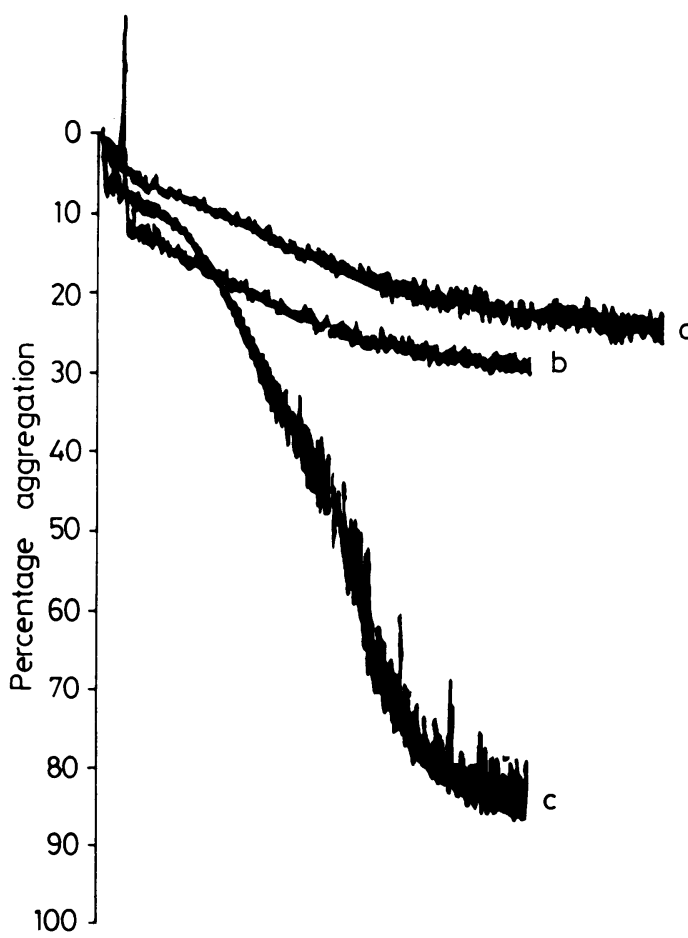

Fig. 3 Ristocetin-induced aggregation of platelets from a Nigerian in group II. (a) Platelet-rich plasma. (b) Albumin-gradient isolated platelets $(A G P)$ in own reconstituted platelet-poor plasma. (c) AGP in human fibrinogen and gamma-globulin solution. 
Table 2 Effects of Nigerian group II and European plasma on ristocetin-induced aggregation of control European washed platelets

\begin{tabular}{ll}
\hline $\begin{array}{l}\text { Ristoceitn }(1 \mathrm{mg} / \mathrm{ml}) \text {-induced aggregation } \\
\text { with normal washed platelets }\end{array}$ & Velocity (\%) \\
\hline+4 European plasma (half diluted) & $70 \pm 8$ \\
+19 Nigerian plasma (half diluted) & $40 \pm 8$ \\
\hline
\end{tabular}

Table 3 Factor VIII activities and ristocetin-induced platelet aggregation in two Nigerians (group II)

\begin{tabular}{|c|c|c|c|c|}
\hline & \multicolumn{2}{|c|}{ Subject 1} & \multicolumn{2}{|c|}{ Subject 2} \\
\hline & $\begin{array}{l}\text { Whole } \\
\text { plasma }\end{array}$ & $\begin{array}{l}\text { Void } \\
\text { volume }\end{array}$ & $\begin{array}{l}\text { Whole } \\
\text { plasma }\end{array}$ & $\begin{array}{l}\text { Void } \\
\text { volume }\end{array}$ \\
\hline $\begin{array}{l}\text { VWF activity }(\mathrm{U} / \mathrm{dl}) \\
\text { Factor VIIIc activity (U/dl) } \\
\text { Factor VIII } \mathrm{RA}_{\mathbf{A}}(\mathrm{U} / \mathrm{dl})\end{array}$ & $\begin{array}{l}0(6)^{*} \\
120 \\
200\end{array}$ & $70(48) \dagger$ & $\begin{array}{l}O(10)^{*} \\
105 \\
200\end{array}$ & $80(65) \dagger$ \\
\hline
\end{tabular}

* Ristocetin-induced platelet aggregation in presence of whole plasma. † Ristocetin-induced platelet aggregation in presence of globulins + fibrinogen.

were in normal or high concentration (Table 3). The ristocetin-cofactor activity appeared in whole plasma to be $0 \mathrm{U} / \mathrm{dl}$ in both, but their void volume separated by Sepharose 2B filtration contained activity of 70 and $80 \mathrm{U} / \mathrm{dl}$; such results strengthen the hypothesis of the existence of an inhibitor.

\section{FIBRINOGEN}

The fibrinogen level was less than $5 \mathrm{~g} / \mathrm{l}$ in 22 out of 30 Europeans tested and between 5.4 and $6.9 \mathrm{~g} / 1$ in three living in Zaria. The values in group I Nigerians were in the same range as those of the Europeans (Fig. 4), but 17 out of 30 group II Nigerians had fibrinogen levels above $5 \mathrm{~g} / \mathrm{l}(5 \cdot 2-8 \cdot 4 \mathrm{~g} / \mathrm{l})$.

\section{FIBRINOLYSIS}

The euglobulin-lysis time was 180 minutes or more in the 30 Europeans (Fig. 5). Two out of 13 group I Nigerians had similar results, but six had enhanced spontaneous fibrinolytic activity (lysis time 120 minutes or less). There was an even more striking difference in group II Nigerians, of whom 16 out of 25 had a euglobulin-lysis time of 90 to 120 minutes. The figure of 22 Nigerians with a euglobulin-lysis time of 120 minutes or less was significantly different from the number of Europeans $(P<0.01)$.

The euglobulin-lysis time was repeated after venostasis in nine Nigerians in group II, of whom five had a spontaneous euglobulin-lysis time of 150 minutes or more and four had shorter times. All had a normal enhancement of fibrinolytic activity approximately in proportion to their spontaneous activity (Table 4).

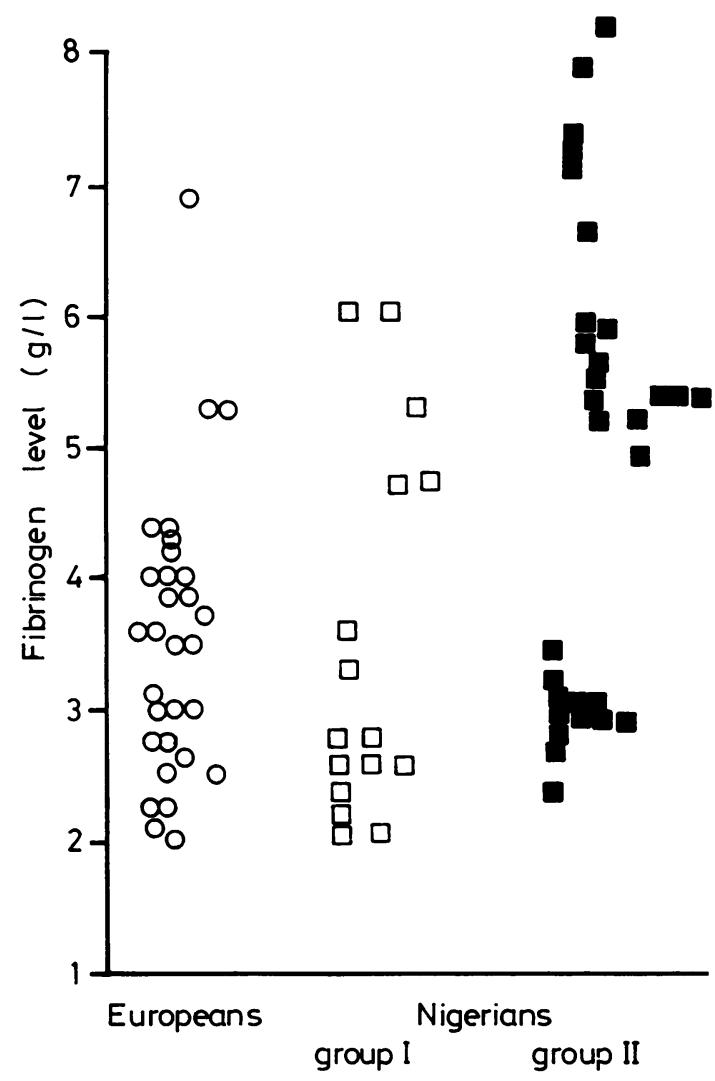

Fig. 4 Fibrinogen levels in Europeans and Nigerians, groups I and II, in Zaria.

\section{Discussion}

The present observations (Fig. 1) confirm that the platelet count of symptom-free Nigerians is frequently lower than the internationally accepted normal range of $150-400 \times 10^{9} / 1(150000-400000 /$ $\mu$ l) (Dacie and Lewis, 1975) in both the forest and derived savanna areas of the south (Essien et al., 1973; Udeozo and Odfelt, 1974; Isaacs-Sodeye et al., 1975) and in the Guinea savanna of the north of Nigeria (Atanu et al., 1974). Nigerian newborns have counts which are similar to those of European newborns and higher than those of adult Nigerians (Effiong et al., 1976), which suggests strongly that the relative thrombocytopenia in adults is acquired. The platelet count falls after acute Plasmodium falciparum (Beale et al., 1972; Skudowitz et al., 1973; Essien and Oruamabo, 1976) and $P$. vivax parasitaemia (Hill et al., 1964; Beale et al., 1972): various mechanisms are involved, including direct invasion of platelets (Fajardo and Tallent, 1974), 


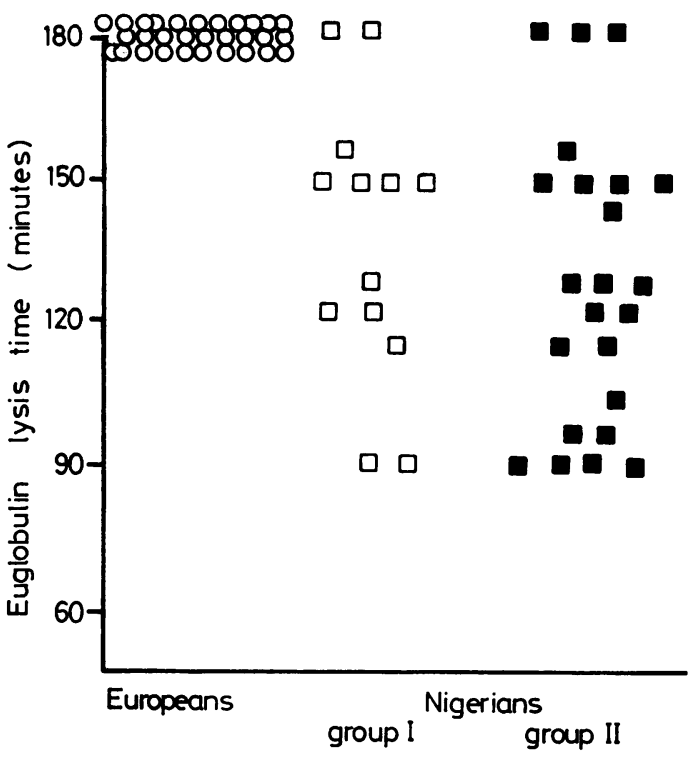

Fig. 5 Euglobulin-lysis time in Europeans and Nigerians, groups I and II, in Zaria.

Table 4 Euglobulin-lysis time before and after venostasis in nine Nigerians group II

\begin{tabular}{lll}
\hline Subject & $\begin{array}{l}\text { Before venostasis } \\
\text { (minutes) }\end{array}$ & $\begin{array}{l}\text { After venostasis } \\
\text { (minutes) }\end{array}$ \\
\hline 1 & 180 & 50 \\
2 & 180 & 60 \\
3 & 150 & 60 \\
4 & 150 & 60 \\
5 & 150 & 60 \\
6 & 120 & 40 \\
7 & 90 & 30 \\
8 & 90 & 30 \\
9 & 90 & 40 \\
\hline
\end{tabular}

shortened survival, splenic pooling (Beale et al., 1972; Skudowitz et al., 1973), and consumption associated with intravascular coagulation (Areekul et al., 1971; Bain, 1973; Essien and Oruamabo, 1976). Other parasitic infections may also lower the platelet count: Trypanosoma rodesiense has been shown to cause thrombocytopenia in rats, and the trypanosomes in vitro aggregate the platelets of rat, rabbit, and man (Davis et al., 1974).

The average spleen-weight in Lagos has been shown to be twice that in London (Bruce-Chwatt, 1956), and the permanent lowering of platelet counts in adult Nigerians is likely to be the result of recurrent malaria-parasitaemia and other infections leading to some degree of hypersplenism.

There have been few studies of platelet function in Africans. Shaper (1974) found no difference in platelet adhesiveness in middle-aged European, Asian, and African men in Uganda. Retief and $\underline{\underline{\sigma}}$ Vandenplas (1970) reported that a small series of Bantus with similar platelet counts to South African whites also had similar ivy bleeding-time, $\bar{C}$ platelet-factor 3 content, clot-retraction, and platelet aggregation with ADP, noradrenaline, collagen, and thrombin; however, the Bantus had less early in vivo adhesion of platelets by the Borchgrevink test, but adhesion to glass according to the technique of Wright was increased. Essien et al. (1973) suggested that platelet-factor 3 was more readily available in Nigerian platelets; Essien and Ebhota (1977) have shown that higher concentrations of ADP, thrombin, and ristocetin are required than in standard tests in order to obtain normal aggregation-responses with Nigerian platelets.

Low platelet numbers were associated with decreased platelet function in Nigerians compared $\$$ to Europeans of the present series. Isolated Nigerian 을 platelets aggregated normally with ADP either in the presence of gamma-globulins and fibrinogen or their own plasma (Table 1), but there was a rapid disaggregation after ADP-induced aggregation in both groups of Nigerians, similar to that described in the inhabitants of the Andes plateau (Caen et al. 1973/74). The most striking observation was th low or absent ristocetin-induced aggregation of platelets in group II Nigerians (Fig. 2); the aggrega tion of platelets in group I Nigerians was intermediate between that of group II and the Europeans, suggesting an environmental rather than a genetic cause.

Nigerian platelets isolated from their own plasma aggregated normally with ristocetin (Fig. 3) and Nigerian plasma inhibited the aggregation of control European platelets with ristocetin (Table 2).

Factor VIII $_{R A}$ was high in two Nigerians in group II, but the VWF was not measurable in whole plasma, at least using dilutions from $1 / 2$ to $1 / 8$; after gel filtration, the VWF activity appeared to be normal when it was measured in the void volume (Table 3 ). All these results suggest that Nigerian whole plasma contained an inhibitory factor acting on the VWF activity. Ristocetininduced aggregation as well as platelet adhesion to subendothelium require normal platelet-membrane glycoprotein I (Nurden and Caen, 1975) and normal VWF (Tschopp et al., 1974). The component found in Nigerian plasma could modify the interaction between ristocetin, platelet-glycoprotein I, and VWF and so inhibit ristocetin-induced platelet aggregation.

Various inhibitors of adhesiveness or ristocetininduced aggregation of platelets have been demonstrated in vitro. Avnur et al. (1977) have shown that 
PRP contains an inhibitor of the adhesion of platelets to glass beads. High concentrations of fibrinogen in vitro inhibit ristocetin-induced platelet aggregation (Stibbe and Kirby, 1976), but the raised fibrinogen levels in the plasma of group II Nigerians (Fig. 4) probably would not be sufficient to explain the observed lack of aggregation. Macroglobulins such as dextran are also known to inhibit ristocetininduced platelet aggregation (Åberg et al., 1975). Nigerians have an average high plasma gammaglobulin, including IgM and other macroglobulins, elevations being greater in rural than in urban populations and in group II than in group I (Edozien et al., 1960; Mohammed et al., 1973). It is suggested that ristocetin-induced aggregation could have been inhibited in Nigerians by these plasma-proteins. Alternatively, as the ratio factor $\mathrm{VIII}_{\mathrm{RA}} / \mathrm{VWF}$ was high, there could have been an excessive synthesis by endothelial cells (Jaffe et al., 1973) of a functionally abnormal VIII $_{\mathrm{RA}}$ protein or of a normal protein which was inactivated or degraded. Factor VIII degradation products could also interact with normal VWF and inhibit platelet aggregation induced by both ristocetin and ADP (Culasso et al., 1974).

Many studies have shown that the fibrinolytic activity is enhanced in Africans compared to Europeans (Antonis and Bersohn, 1961; Menon, 1967; Szczeklik et al., 1975). Black but not white Americans demonstrated a decrease of resting fibrinolytic activity and alpha-1-antitrypsin with a rise in social class (Franz et al., 1975). Similarly, the spontaneous fibrinolytic activity was greater in group II than in group I (Fig. 5). It was enhanced normally by venostasis in proportion to the initial activity (Table 4), which agrees with the observation of Franz et al. (1975) of greater activator-activity in the venous walls of blacks than whites in South Africa. This high spontaneous fibrinolytic activity with a normal response to venostasis could be associated with more frequent and strenuous muscular exercise, diets low in unsaturated fats and with high residue (Barr et al., 1973; Burkitt, 1972), or the particular healthy endothelium in Nigerians with few atheromatous lesions (Akinkugbe, 1972).

The relative freedom of Africans in a rural environment from the complications of atheromatous disease is well established, and the roles of diet and physical activity have been extensively discussed. An immunity from the complications of thrombosis may be explained to a large extent by the low platelet count, early disaggregation after ADP-induced platelet aggregation, inhibition of ristocetin-induced aggregation with a possible in vivo modification of the platelet-VWF-subendothelial interaction, and high fibrinolytic activity. In addition, the present observations suggest a mechanism preventing the formation of atheroma itself. When the endothelium is damaged, platelets adhere to subendothelial tissue and undergo degranulation; this is followed by proliferation of smooth cells, which appears to be the response to a mitogenic agent released by platelets (Ross et al., 1974; Fuster et al., 1975; Busch and Westermark, 1975; Harker et al., 1976). It may be hypothesised that inhibition of the interaction of platelets, VWF, and subendothelium could protect Africans against the development of intimal hyperplasia and atheroma, as the platelets are not strongly adherent and there is only limited release of the mitogenic agent. This mechanism has been postulated to explain immunity from atheroma in pigs with von Willebrand's disease (Bowie et al., 1975).

We thank Professor H. M. Gilles, Liverpool School of Tropical Medicine, for the loan of the aggregometer and for his encouragement. We acknowledge the support of CNRS, ATP 'Physiologie-écologie', 1974, 1833. The Educational Aids Unit, Faculty of Medicine, Ahmadu Bello University prepared the figures.

\section{References}

Åberg, M., Hedner, U., Holmberg, L., and Bergentz, S. E. (1975). Dextran induced changes of the factor VIII molecule (Abstract). Thrombosis et Diathesis Haemorrhagica, 34, 903.

Akinkugbe, O. O. (1972). High Blood Pressure in the African, pp. 81-89. Churchill Livingstone, Edinburgh and London.

Antonis, A., and Bersohn, I. (1961). Blood fibrinolytic activity in white and Bantu subiects (Letter). Lancet, 1, 401-402.

Areekul, S., Kanakakorn, K., Kasemsuth, R., Boonyananta, C., and Matrakul, D. (1971). ${ }^{131}$ I-fibrinogen metabolism and fibrinolytic activity in Plasmodium falciparum malaria. Journal of the Medical Association of Thailand, 54, 911-919.

Atanu, D. O., Omeje, J. U., and Fleming, A. F. (1974). Haemoglobin concentration, haematocrit platelet count and white cell count of blood donors in Zaria (Abstract). Nigerian Medical Journal, 4, 129.

Avnur, Z., Nathan, I., Dvilansky, A., and Livne, A. (1977). Plasma constituent(s) inhibiting platelet adhesiveness. Israel Journal of Medica! Science, 13, 264-271.

Bain, B. (1973). Disseminated intravascular coagulation in benign tertian malaria (Letter). British Medical Journal, 1, 550.

Barr, R. D., Ouna, N., and Kendall, A. G. (1973). The blood coagulation and fibrinolytic enzyme systems in healthy adult Africans and Europeans-a comparative study. Scottish Medical Journal, 18, 93-97.

Beale, P. J., Cormack, J. D., and Oldrey, T. B. N. (1972). Thrombocytopenia in malaria with immunoglobulin 
(IgM) changes. British Medical Journal, 1, 345-349. Bowie, E. J. W., Fuster, V., Owen C. A., Jr., and Brown, A. L. (1975). Resistance to the development of spontaneous atherosclerosis in pigs with von Willebrand's disease (Abstract). Thrombosis et Diathesis Haemorrhagica, 34, 599.

Bruce-Chwatt, L. J. (1956). Biometric study of spleenand liver-weights in Africans and Europeans, with special reference to endemic malaria. Bulletin of the World Health Organisation, 15, 513-548.

Burkitt, D. P. (1972). Varicose veins, deep vein thrombosis and haemorrhoids: epidemiology and suggested etiology. British Medical Journal, 2, 556-561.

Busch, C., and Westermark, B. (1975). A growth factoranother product of the platelet release reaction? (Abstract). Thrombosis et Diathesis Haemorrhagica, 34, 907.

Caen, J. P., Drouet, L., Bellanger, R., Michel, H., and Hénon, P. (1973/74). Thrombosis, platelet behaviour, fibrinolytic activity and diet on the Andes Plateau. Haemostasis, 2, 13-20.

Caen, J. P., Ergueta, J., Michel, H., Daufresne, A., Poupart, C., and Dhuime, G. (1971). Modifications de l'agrégation plaquettaire à l'adénosine diphosphate (ADP) chez les Boliviens et les Péruviens de l'Altiplano: étude statistique. Comptes Rendus Hebdomadaires de Séances de l'Académie des Sciences, D, 272, 505-508.

Caen, J. P., Larrieu, M. J., and Samama, M. (1975). L'Hémostase: Méthodes d'Exploration et Diagnostic Pratique, 2nd edition. Expansion Scientifique Française, Paris.

Culasso, D. E., Donati, M. B., de Gaetano, G., Vermylen, J., and Verstraete, M. (1974). Inhibition of human platelet aggregation by plasmin digests of human and bovine fibrinogen preparations: role of contaminating factor VIII-related material. Blood, 44, 169-175.

Dacie, J. V., and Lewis, S. M. (1975). Practical Haematology, 5th edition, p. 57. Churchill Livingstone, Edinburgh and London.

Davis, C. E., Robbins, R. S., Weller, R. D., and Braude, A. I. (1974). Thrombocytopenia in experimental trypanosomiasis. Journal of Clinical Investigation, 53, 1359-1367.

Edington, G. M., and Gilles, H. M. (1975). Pathology in the Tropics, 2nd edition, pp. 377-379. E. Arnold, London.

Edozien, J. C., Boyo, A. E., and Morley, D. C. (1960). The relationship of serum gamma-globulin concentration to malaria and sickling. Journal of Clinical Pathology, 13, 118-123.

Effiong, C. E., Usanga, E. A., and Mellits, E. D. (1976). Platelet counts in healthy full-term Nigerian neonates. Tropical and Geographical Medicine, 28, 329-332.

Essien, E. M., and Ebhota, M. I. (1977). The pattern of response of human platelets to some external stimuli. 3rd Joint Conference of the Nigerian Society for Immunology, Nigerian Society for Haematology and Blood Transfusion and Association of Pathologists of Nigeria, Ibadan. Abstracts p. 23.

Essien, E. M., and Oruamabo, R. S. (1976). Depression of platelet count during acute falciparum malaria infection. 2nd International Conference on Paediatrics in the Tropics, Ibadan. Abstracts, p. 16.

Essien, E. M., Usanga, E. A., and Ayeni, O. (1973). The normal platelet count and platelet factor 3 availability in some Nigerian population groups. Scandinavian Journal of Haematology, 10, 378-383.

Fajardo, L. F., and Tallent, C. (1974). Malarial parasites within human platelets. Journal of the American Medical Association, 299, 1205-1207.

Franz, R. C., Hugo, N., and Jansen, C. R. (1975). The histochemical assay of plasminogen activator in the venous-wall: an inter-ethnic study (Abstract). Thrombosis et Diathesis Haemorrhagica, 34, 608-609.

Fuster, V., Kottke, B. A., Ruiz, C. E., Lewis, J. C., Bowie, E. J. W., and Owen, C. A., Jr. (1975). Studies on platelet factor 4 like activity in atherosclerosis susceptible and resistant pigeons (Abstract). Thrombosis et Diathesis Haemorrhagica, 34, 601.

Harker, L. A., Ross, R., Slitcher, S. J., and Scott, C. R. (1976). Homocystine-induced arteriosclerosis. The role of endothelial cell injury and platelet response in its genesis. Journal of Clinical Investigation, 58, 731-741.

Hill, G. J., Knight, V., and Jeffery, G. M. (1964). Thrombocytopenia in vivax malaria. Lancet, 1, 240-241.

Isaacs-Sodeye, W. A., Ukaejiofo, E. D., and Ayeni, O. (1975). Haematological normal values-survey of several segments of the population of Ibadan. 1st Joint Conference of the Nigerian Society for Immunology, Nigerian Society for Haematology and Blood Transfusion and Association of Pathologists of Nigeria, Enugu. Abstracts, no. 63.

Jaffe, E. A., Hoyer, L. W., and Nachman, R. L. (1973). Synthesis of antihemophilic factor antigen by cultured human endothelial cells. Journal of Clinical Investigation, 52, 2757-2764.

Lacombe, M. J., Sultan, Y., and Caen, J. P. (1971) Défaut d'activation du systéme fibrinolytique après anoxie locale dans trois cas de maladie thromboembolique. Presse Médicale, 79, 751-754.

Menon, I. S. (1967). Fibrinolytic activity in the blood of Nigerian students after four years residence in the United Kingdom. Laboratory Practice, 16, 574-577. Mohammed, I., Tomkins, A. M., and Greenwood, B. M. (1973). Normal immunoglobulins in the Tropics (Letter). Lancet, 1, 481.

Nicholls, D. G., and Hampton, J. R. (1972). Density gradient separation of human platelets from plasma and the role of plasma in adenosine diphosphate induced platelet electrophoretic mobility changes. Thrombosis et Diathesis Haemorrhagica, 27, 425-433.

Nurden, A. T., and Caen, J. P. (1975). Specific roles for platelet surface glycoproteins in platelet function. Nature, 255, 720-722.

Parry, E. H. O., and Ikeme, A. C. (1966). Cardiovascular Disease in Nigeria, pp. 81-86. Ibadan University Press, Ibadan.

Restrepo, C. (1974). Atherosclerosis. In Cardiovascular Disease in the Tropics, edited by A. G. Shaper, M. S. R. Hutt, and Z. Fejfar, pp. 125-147. British Medical Association, London.

Retief, F. P., and Vandenplas, L. (1970). Platelet function in the Bantu. Atherosclerosis, 12, 173-180. 
Ross, R., Glomset, J., Kariya, B., and Harker, L. (1974). A platelet-dependent serum factor that stımulates the proliferation of arterial smooth muscle cells in vitro. Proceedings of the National Academy of Sciences of the United States of America, 71, 1207-1210.

Shaper, A. G. (1974). Coronary heart disease. In Cardiovascular Disease in the Tropics, edited by A. G. Shaper, M. S. R. Hutt, and Z. Fejfar, pp. 148-159. British Medical Association, London.

Skudowitz, R. B., Katz, J., Lurie, A., Levin, J., and Metz, J. (1973). Mechanisms of thrombocytopenia in malignant tertian malaria. British Medical Journal, 2, 515-518.

Stibbe, J., and Kirby, E. P. (1976). The influence of Haemaccel, fibrinogen and albumin on ristocetininduced platelet aggregation. Relevance to the quantitative measurement of the ristocetin cofactor. Thrombosis Research, 8, 151-165.
Szczeklik, A., Dischinger, P., Keuppers, F., Tyroler, H. A., Hames, C. G., Cassel, J., and Creagan, S. (1975). Comparative study of blood fibrinolytic activity and its inhibitors in US Blacks and Whites (Abstract). Thrombosis et Diathesis Haemorrhagica, 34, 950-951.

Tschopp, T. B., Weiss, H. J., and Baumgartner, H. R. (1974). Decreased adhesion of platelets to subendothelium in von Willebrand's disease. Journal of Laboratory and Clinical Medicine, 83, 296-300.

Udeozo, I. O. K., and Odfelt, A. M. (1974). Haematological studies of healthy Ibos of East Central State, Nigeria (Abstract). Nigerian Medical Journal, 4, 125.

Requests for reprints to: Professor J. P. Caen, Department of Haemostasis and Experimental Thrombosis, Hôpital Lariboisière, 2 rue Ambroise Paré, 75475 Paris, Cedex 0 , France.

\section{Reports and Bulletins prepared by the Association of Clinical Biochemists}

The following reports and bulletins are published by the Association of Clinical Biochemists. They may be obtained from The Publishing Department, British Medical Journal (ACB Technical Bulletins), B.M.A. House, Tavistock Square, London WC1H 9JR. Overseas readers should remit by British Postal or Money Order.

SCIENTIFIC REVIEWS (price $£ 1 \cdot 00 / \$ 2.00$ each)

1 The assessment of thyroid function March 1971 F. V. FLYNN and J. R. HOBBS

2 Renal function tests suitable for clinical practice January 1972 F. L. MITCHELL, N. VEALL, and R. W. E. WATTS

3 Biochemical tests for the assessment of fetoplacental function May 1975 C. E. WILDE and R. E. OAKEY

4 Test of exocrine pancreatic function March 1977 A. H. GOWENLOCK

TECHNICAL BULletins (price $£ 1 \cdot 00 / \$ 2.00$ each)

22 Bilirubin standards and the determination of bilirubin by manual and technicon AutoAnalyzer methods January 1971 BARBARA BILLING, RUTH HASLAM, and $\mathrm{N}$. WALD

23 Interchangeable cells for spectrophotometers and fluorimeters September 1971 s. S. BROWN and A. H. GOWENLOCK

24 Simple tests to detect poisons March 1972 B. W. MEADE et al.

25 Blood gas analysers May 1972 K. DIXON

26 Kits for enzyme activity determination September 1972 s. B. ROSALKI and D. TARLOW

27 Assessment of pumps suitable for incorporation into existing continuous flow analytical systems November 1972 A. FLECK et al.
28 Routine clinical measurements of transferrin in human serum September 1973 K. DIXON

29 Control materials for clinical biochemistry (5th edition) September 1973 J. F. STEVENS

30 Notes on the quality of performance of serum cholesterol assays September 1973 s. s. BROWN

31 Determination of uric acid in blood and in urine July 1974 R. W. E. WATTS

32 A survey of amino acid analysers readily available in the United Kingdom September 1974 J. e. CARLYLE and P. PURKISS

33 Definitions of some words and terms used in automated analysis November 1974 A. FLECK, R. ROBINSON, S. S. BROWN, and J. R. HOBBS

34 Measurement of albumin in the sera of patients January 1975 LINDA SLATER, P. M. CARTER, and J. R. HOBBS

35 Investigation of the validity of temperature correction factors for serum aspartate and alanine transaminases March 1975 s. B. ROSALKI et al.

36 Factors influencing the assay of creatinine November 1975 J. G. H. COOK

37 A survey of enzyme reaction rate analysers readily available in the United Kingdom July 1977 R. A. SAUNDERS and R. F. BURNS

38 Transport of specimens for clinical chemistry analysis November 1977 P. WILDING, J. F. ZILVA, and C. E. WILDE

39 A scheme for the evaluation of diagnostic kits May 1978 P. H. LLOYD 